\title{
FLUID INCLUSION STUDY OF THE POLYMETALLIC EPITHERMAL QUARTZ VEINS AT SORIPESA PROSPECT AREA, SUMBAWA ISLAND, INDONESIA
}

\author{
Win Kant ${ }^{* 1,2}$, I Wayan Warmada ${ }^{1}$, Arifudin Idrus ${ }^{1}$, Lucas Donny Setijadji ${ }^{1}$, and Koichiro \\ Watanabe $^{3}$ \\ ${ }^{1}$ Department of Geological Engineering, Gadjah Mada University, Yogyakarta, Indonesia \\ ${ }^{2}$ Department of Geology, Banmaw University, Myanmar \\ ${ }^{3}$ Department of Earth Resource Engineering, Kyushu University, Japan
}

\begin{abstract}
The Soripesa prospect area is located at Maria village, Wawo district, Bima region in the eastern part of Sumbawa Island, Indonesia. This area is a part of Cenozoic Calc-alkaline volcanic inner Banda-Sunda Arc. The dominant lithology of Soripesa prospect area are a lithic-crystal tuff of andesitic and dacitic composition and bedded limestone. There have five main polymetallic epithermal quartz veins in the Soripesa prospect area, namely, Rini vein, Jambu air vein, Dollah vein, Merpati vein, and Arif vein. Those quartz veins are hosted mainly in andesitic volcaniclastic rocks. Fluid inclusion study on those quartz veins is vey important to know the condition of hydrothermal fluids and their origin. Fluid inclusion study is conducted at the laboratory of Earth Resources Engineering Department, Kyushu University, Japan. Homogenization temperature, freeze temperature, eutectic temperature, and melting temperature can be known from fluid inclusion study. Based on fluid inclusion study, formation temperatures of all veins are between $250-260^{\circ} \mathrm{C}$. Melting temperature is between -0.2 to $-3^{\circ} \mathrm{C}$. Based on the melting temperature, salinity (wt.\% $\mathrm{NaCl}$ equiv.) of fluid inclusions is calculated by using Bodnar's equation. Paleodepth of formations and pressure of
\end{abstract}

${ }^{*}$ Corresponding author: W. KANT, Department of Geological Engineering, Faculty of Engineering, Gadjah Mada University, Jl. Grafika 2 Yogyakarta, 55281, Indonesia. E-mail: winkant1995@gmail.com trapping are also estimated by using formation temperature and salinity. Based on Hass (1971) diagram, estimated paleodepths of formations are 270 $m$ for Merpati vein, $400 m$ for Dollah vein, $480 \mathrm{~m}$ for Rini vein, $570 \mathrm{~m}$ for Arif vein, and $680 \mathrm{~m}$ for Jambu Air vein, respectively. Pressure of trapping can also be estimated from depth of formation, density of lithostatic overburden, and gravity; 72 bars for Merpati vein, 106 bars for Dollah vein, 127 bars for Rini vein, 151 bars for Arif vien, and 180 bars for Jambu Air vein, respectively.

Keywords: Soripesa, polymetallic quartz veins, homogenization temperature, salinity.

\section{Introduction}

Introduction The Soripesa prospect area is located at Maria village, Wawo district, Bima region in the West Nusa Tenggara Province. The prospect area is previously owned by PT Bima Baruna Raya Mining (BBRM) and PT Sumbawa Timur Mining. These companies have observed Au-Ag deposit and base metal mineralization. At present, PT Bima Putera Minerals (Indomining Group) has a Mining Permit for those deposits. The prospect area is mainly composed of andesitic and dacitic volcaniclastic host rocks and small amount of Tertiary bedded limestones. Merpati vein, Dollah vein, Rini vein, Arif vein, and Jambu Air 
veins (polymetallic epithermal quartz veins) occur in Soripesa prospect area. Those five quartz veins are hosted in andesitic volcaniclastic rocks. They are trending nearly north-south because of regional structure. The main ore minerals are chalcopyrite, azurite, malachite, sphalerite and galena forming as polymetallic epithermal quartz veins.

The purpose of this paper is to determine the formation temperature, pressure, depth, and to identify the fluid condition of polymetallic epithermal quartz veins at Soripesa prospect area, East Sumbawa, Indonesia.

\section{Tectonic Setting}

Soripesa prospect area is located in the eastern part of Sumbawa Island and in the eastern part of Sunda-Banda arc (Neogene). Sunda-Banda island arc is a volcanic arc formed by the interaction of plate subduction slab in the form of Indo-Autralia with Asian plate (Mitchael and Carry, 2000). Sunda-Banda arc is still active up to present and is the longest in Indonesia, extending from north Sumatra through Java, Bali, Lunbawk, and Sumbawa, to east Damar. The shape of the island arc is now being modified in the east due to collision with the Australian-New Guinea continental margin, including West Flores to East Sumbawa and Alor (Hamilton, 1979). Figure 1 shows the tectonic setting and location map of the Sumbawa Island, Indonesia.

The East Sumbawa area is largely underlain by andesitic to basaltic lava and breccia of the Lower Miocene, with intercalations of tuff and limestone, and fresh pyroclastic sequences (Noya et al, 2009). This sequence is overlain in parts by dacitic tuff and bedded limestone of the Mid Miocene. These units have been intruded by numerous small to medium bodies (several km's) in the Middle to Upper Miocene including andesite, dacite, diorite, trachyte and syenite (Figure 2). Sumbawa Island, regionally, is intersected by NW-SE and NE-SW trending structures. However, the formation of quartz veining, alteration and mineralization at Soripesa Prospect are related to the N-S faulting (Noya et al, 2009).

\section{Mineralization}

The main vein zones which are associated with precious metals (Au-Ag) and base metals $(\mathrm{Cu}$, $\mathrm{Pb}, \mathrm{Zn}$ ) are Rini, Jambu Air, Merpati, Arif, and Dollah epithermal quartz veins (Figure 3). They are nearly vertical $\left(>70^{\circ}\right), 1-16 \mathrm{~m}$ thick with individual vein to $1000 \mathrm{~m}$ length. The vertical outcrop of Rini vein can be observed in the field and it may reach up more than $200 \mathrm{~m}$.

The quartz vein and alteration area have a size of $6.7 \times 4.7 \mathrm{~km}^{2}$ or \pm 3150 hectares (Noya et al, 2009). Quartz textures of those veins belong to typical characters of low-sulphidation epithermal system and they can help to identify the morphology of veins such as facecontrolled and parallel-controlled. These parallel-controlled and face-controlled indicate that the epithermal quartz veins in the Soripesa prospect area are formed at the near surface (Khant et al, 2012). Within the veins, multiphases, vuggy, colloform, bedded to massive textures with chalcopyrite, galena, sphalerite, malachite, azurite, chalcocite, pyrite, and iron oxide minerals are observed.

Weak to moderate clay-pyrite alteration intensively developed in the volcanic rocks, especially in the west side of Soripesa. It could be influenced by NW-SE trending structures and andesite to porphyry dacite intrusive rock. The common alteration minerals in this prospect area are quartz, epidote, chlorite, pyrite, illite, and smectite. Minor amount of other alteration minerals are kaolinite, alunite, rutile, and anatase (Khant et al, 2012). Temperaturesensitive minerals include Ca-silicates such as epidote and chlorite (stable above $200-240^{\circ} \mathrm{C}$ ), near the base of the epithermal environment. At the edges of the quartz veins develop silicaclay-chlorite alteration; outward has changed to chlorite-epidote \pm magnetite as the halo alteration.

\section{Sampling and Analytical Nethods}

Selected 5 quartz samples from 5 main veins were analyzed for fluid inclusion study at the Department of Earth Resources Engineering and Research Institute of Environment for Sustainability, Kyushu University, Japan. For fluid 


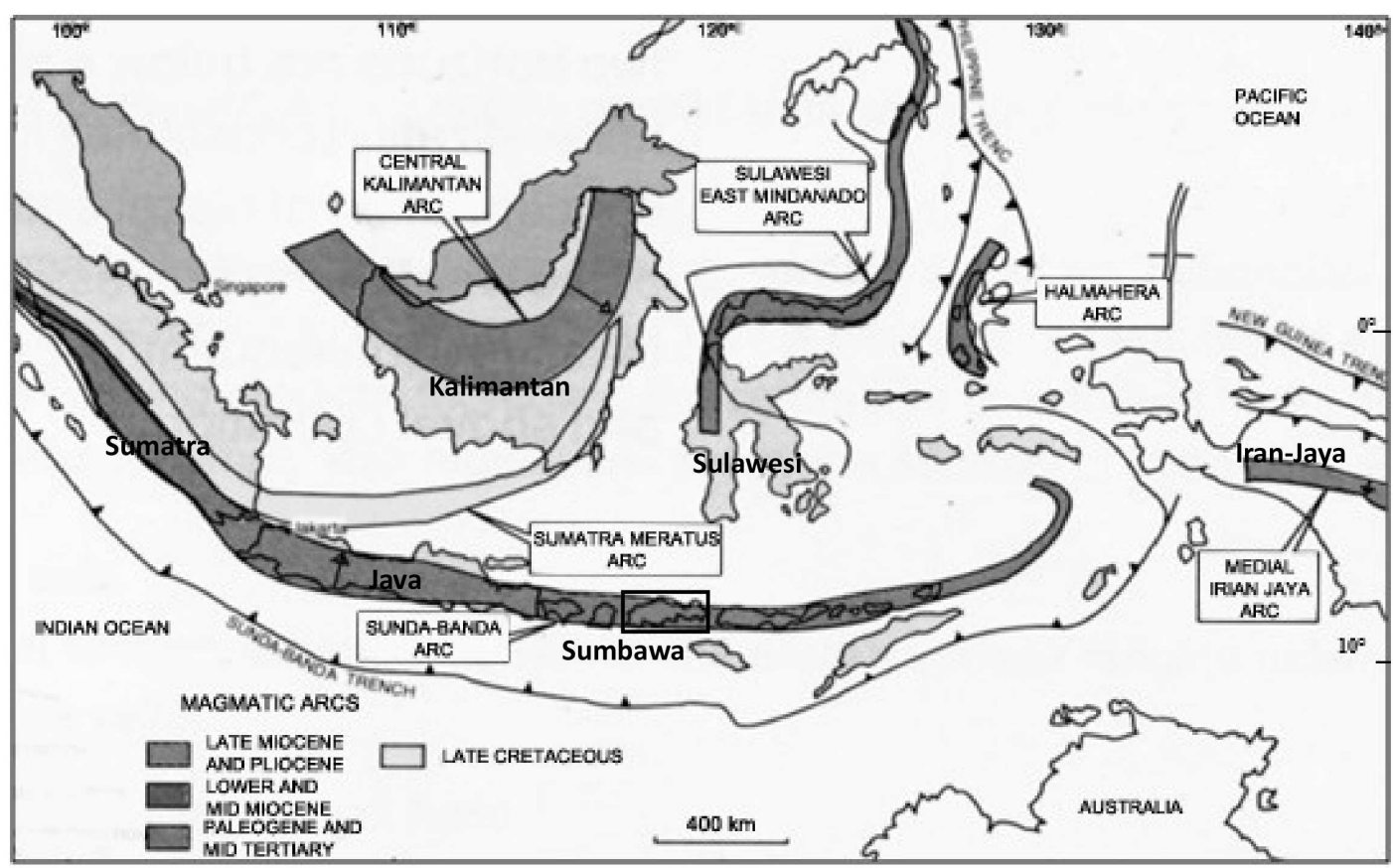

Figure 1: Map showing Sumbawa Island located on Sunda-Banda magmatic arc system and other magmatic arcs (modify after, Carlile and Mitchell, 1994).

inclusion study, samples were made double polished sections and the slice thicknesses are approximately between 100 to $200 \mu \mathrm{m}$. At least about 50 fluid inclusions were measured for one sample. Therefore, over 250 fluid inclusions were measured to get microthermometry data, especially, homogenization temperature and melting temperature. Microthermometry of fluid inclusions was conducted in terms of heating experiments using a USGS adopted fluid inclusion heating stage and also using a heating stage (Linkam microthermometry unit LK-600PM) and freezing stage (Linkam microthermometry unit LK-600A).

Fluid inclusion study is vey important to know the condition of hydrothermal fluids and their origin. Homogenization temperature, freeze temperature, eutectic temperature, and melting temperature can be known from fluid inclusion study. Salinity can be also known from melting temperature by using equation of Bodnar (1993). Salinity $<26.3$ wt.\% NaCl equivalent can be calculated with the following Bondar's formula (only for $\mathrm{H}_{2} \mathrm{O}-\mathrm{NaCl}$ system).

$$
\begin{aligned}
\text { wt. } \% \mathrm{NaCl}= & -1.78 \times T_{m}-0.0442 \times T_{m}^{2} \\
& -0.000557 \times T_{m}^{3}
\end{aligned}
$$

where $T_{m}$ is melting temperature in degrees Celsius. Formation of depth and pressure can be also known by comparing with the homogenization temperature and melting temperature. From those data, the origin and environment of ore deposits can be estimated and conducted the genetic model of ore deposits.

\section{Results and Discussions}

\subsection{Fluid inclusions petrography}

In general, fluid inclusions can be classified into monophase (liquid or vapor), two-phase (liquid+vapor or vapor+liquid), and multiphase (Roedder, 1984). Most fluid inclusions in this research contain two phases (liquid+vapor) and are liquid-rich, with liquid dominating the volume by $>65$ percent (Figure 4). The common size of fluid inclusions in this research is between 10 to $20 \mu \mathrm{m}$. The common shapes of fluid inclusions are nearly circle and some are elongated. Fluid inclusions can also be classified 


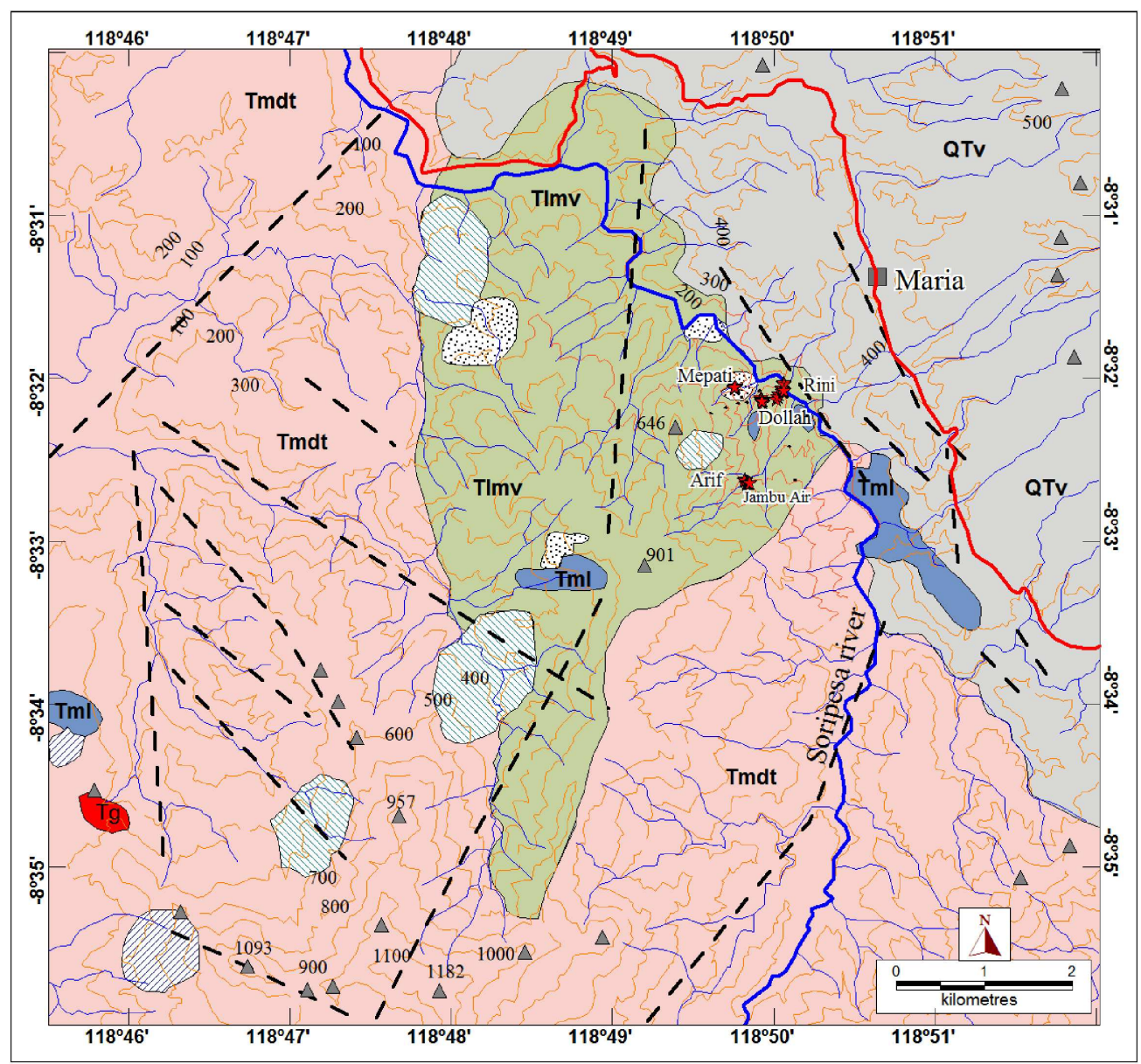

\section{LEGEND}

\begin{tabular}{|l|}
\hline QTv \\
\hline \hline Tg \\
\hline \hline Tmdt \\
\hline \hline Tml \\
\hline \hline TImv \\
\hline
\end{tabular}

Quaternary agglomerate to breccias andesitic volcanic, not consolidated matrix supported with fragments Andesite intrusive

Dacitic volcaniclastic, agglomeratic to breccias gradation to fine-grained tuff

Fossiliferous limestone

Andesitic volcaniclastic, agglomeratic to breccias gradation to fine-grained tuff

Highly silicified + pyrite \pm manganese alteration in places silica has been leached out (gossanous) and contains highly oxidized

Clay-quartz alteration

Chlorite-epidote alteration

Quartz vein with base metals mineralization (azurite, chalcopyrite, malachite, galena, sphalerite, pyrite)

\footnotetext{
- - Fault $\sim$ River and stream

$\Delta$ Spot high

Motor road

Contour (m)
}

Figure 2: Geological map of around Soripesa prospect area (modified after Noya et al, 2009). 

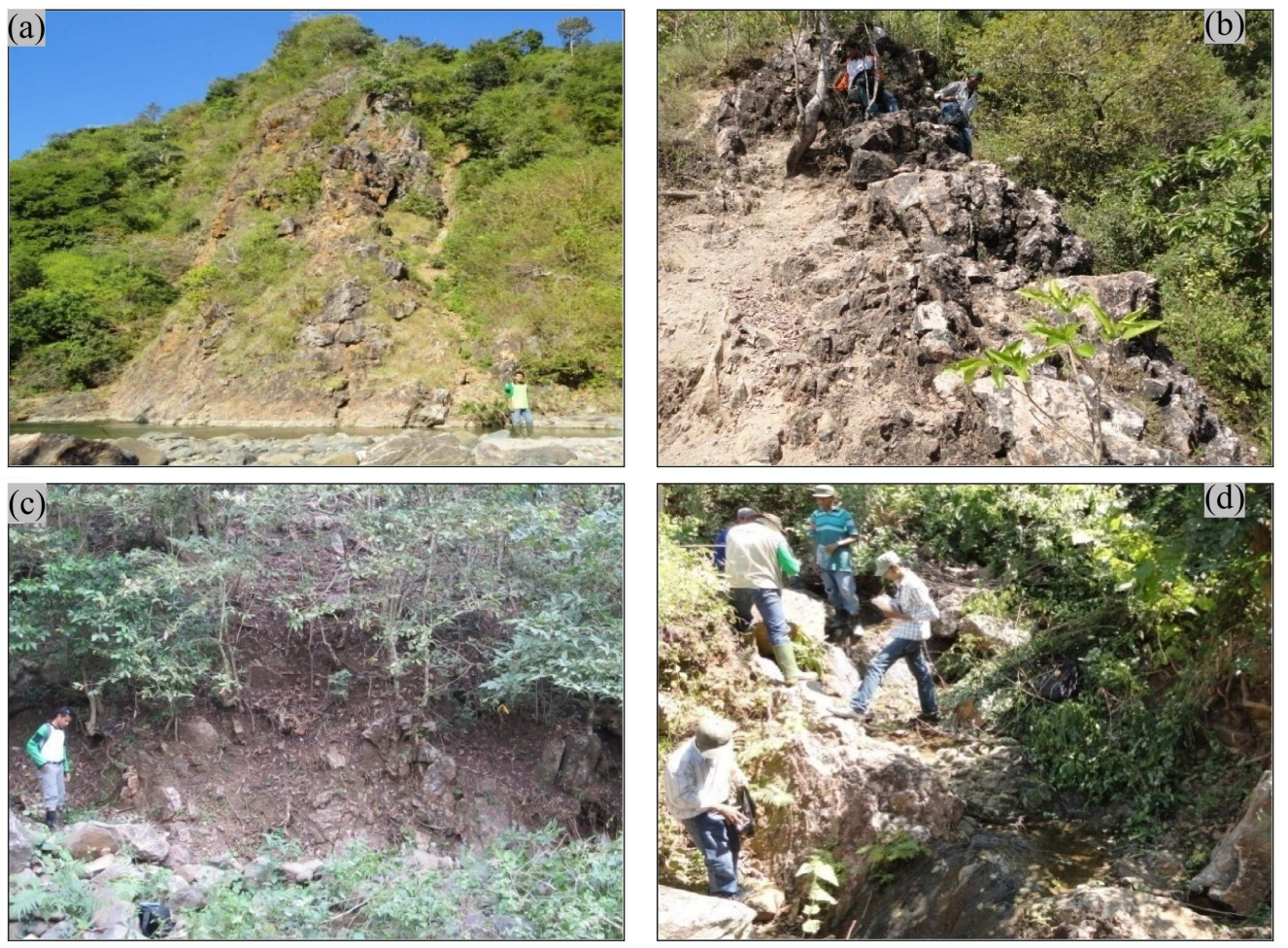

Figure 3: Some quartz veins at Soripesa prospect area (a) Rini vein with width view, (b) Dollah vein, (c) Arif vein with width view, and (d) Merpati vein.

into three types based on their genetic such as primary, secondary, and pseudo secondary. In this research, although secondary necking inclusions are occurred, only primary inclusions are used to conduct the microthermometry values.

\subsection{Microthermometry}

Microthermometry analysis will allow estimating the temperature of homogenization and temperature of melting. In epithermal deposit, fluid inclusion microthermometry results can be used to estimate formation temperature of the deposit and salinity of the responsible hydrothermal fluid. In the relatively low pressure epithermal environment, fluid inclusion homogenization temperatures are no need to do pressure correction to obtain the trapping temperature (Bodnar et al, 1985).

Based on the fluid inclusion data, ranges of homogenization temperature $\left({ }^{\circ} \mathrm{C}\right)$ for Merpati Vein is (182-279), Rini vein (185-266), Dollah vein (212-300), Arif vein (216-300), and Jambu Air vein (233-297). According to the histograms of homogenization temperature, the formation temperature of Merpati Vein is between 220 and $230^{\circ} \mathrm{C}$, Dollah Vein (DV): $240-250^{\circ} \mathrm{C}$, Rini Vein (RV): $250-260^{\circ} \mathrm{C}$, Arif Vein (AV): $260-270^{\circ} \mathrm{C}$, and Jambu Air Vein (JV): $270-280^{\circ} \mathrm{C}$. The results of homogenization temperature are shown in Figure 5. Average melting temperature of each vein is $-1.88^{\circ} \mathrm{C}$ for Merpati vein, $-1.43^{\circ} \mathrm{C}$ for Dollah vein, $-0.93^{\circ} \mathrm{C}$ for Rini vein, $-1.13^{\circ} \mathrm{C}$ for Arif vein, and $-1.08^{\circ} \mathrm{C}$ for Jambu Air vein. Melting temperature is very important for calculating the density of fluid. The results of melting temperature of all veins are shown in Table 1 .

\subsection{Salinity determinations and density}

The fluid inclusion salinity is calculated based on the melting temperature and by using Bodnar's equation (1993). The average salinity of the fluid for all veins is 3.15 for Merpati vein, 2.44 for Dollah vein, 1.6 for Rini vein, 1.95 for Arif vein, and 1.86 for Jambu Air vein (Table 1). Salinity of fluid is also very important to know the fluid evolution processes, density of fluid, depth of formation, and pressure of trap- 

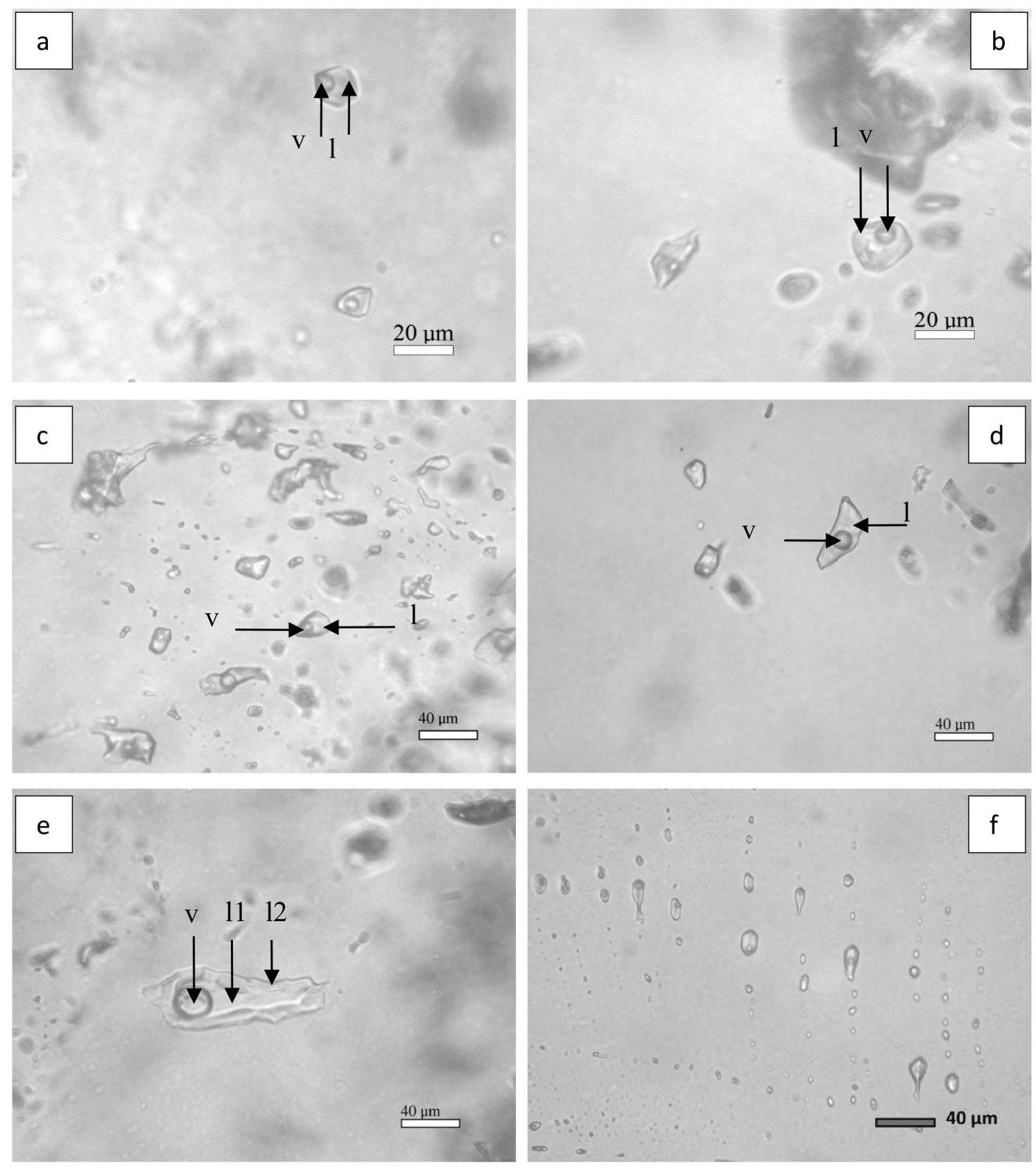

Figure 4: Microphotographs showing liquid-rich fluid inclusions in quartz samples of polymetallic epithermal quartz veins, namely (a) Arif vein (b) Dollah vein (c) Jabmu Air vein (d) Merpati vein (e)Rini vein and (f) necking fluid inclusions from Merpati vein. 

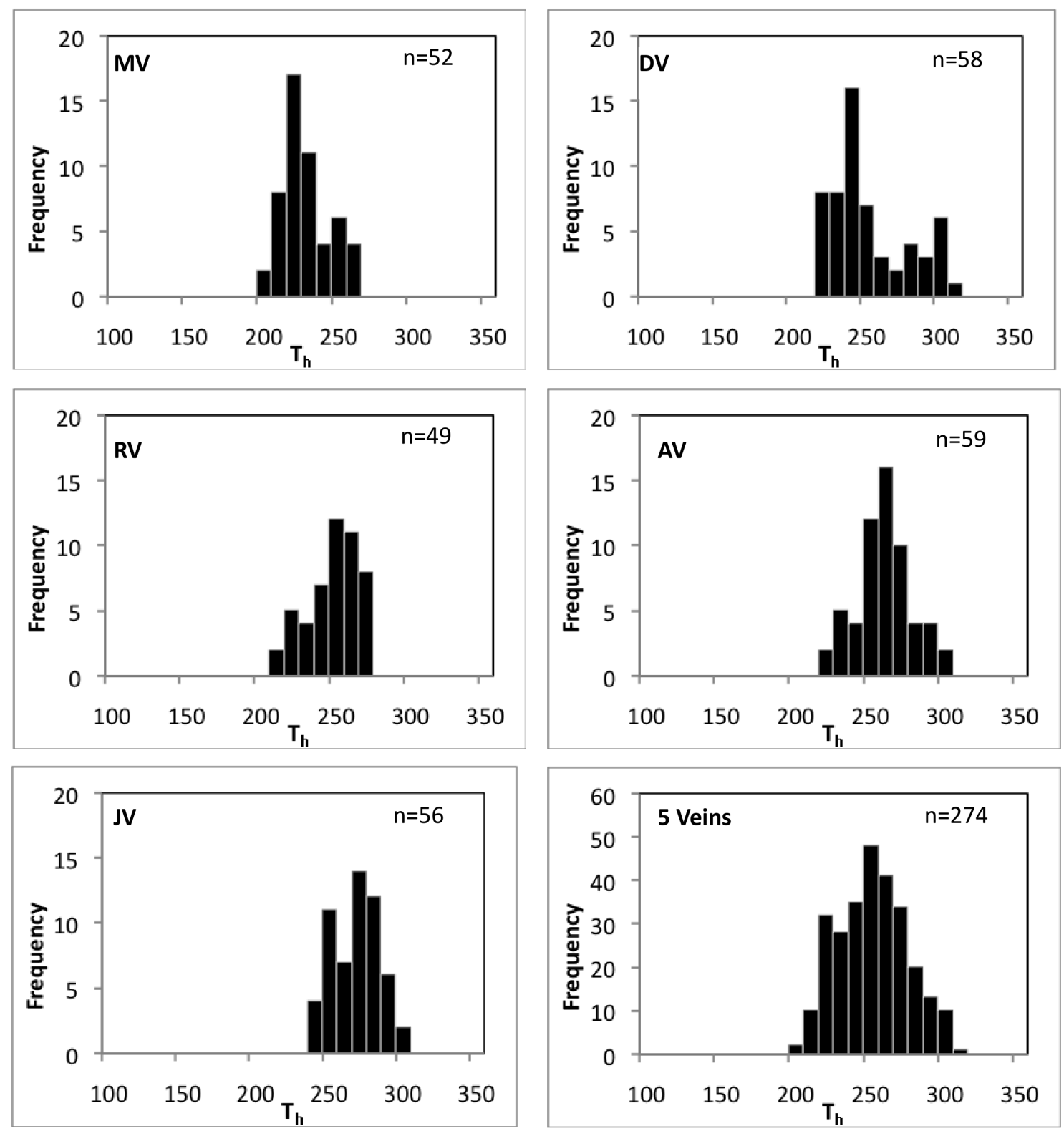

( $\mathrm{n}=$ number of analyzed fluid inclusions)

Low $T_{h}\left({ }^{\circ} \mathrm{C}\right)$ $\operatorname{High} T_{h}\left({ }^{\circ} \mathrm{C}\right)$

MV DV $\quad$ RV $\quad$ AV $\quad \overrightarrow{J V}$

Figure 5: Graphs showing homogenization temperature of 5 veins (MV = Merpati vein, DV = Dollah Vein, RV = Rini Vein, AV = Arif Vein, and JV = Jambu Air Vein). 
ping, and so on. Based on the homogenization temperature ranges (182-305) and average salinity (0-5 wt.\% $\mathrm{NaCl}$ equiv.), polymetallic quartz veins are sure to form under epithermal system (see in Table 2 and Figure 9). Salinity variations can be produced by boiling or effervescence, but significant salinity increases will only occur by continuous boiling in restricted fractures (Wilkinson, 2011).

Significant salinity variations are most likely to be controlled by fluid mixing, except where dissolution of evaporates can be demonstrated (Figure 7). In this research salinity of Merpati vein and Dollah vein show the trends of boiling processes. Salinity of Rini vein and Arif vein show a trend of isothermal mixing (Figure 6). Salinity of Jambu Air vein shows a trend of surface fluid dilution processes. Based on Thsalinity data, fluid inclusion density is between 0.7 and $0.9 \mathrm{~g} \mathrm{~cm}^{-3}$ (Figure 8).

\subsection{Depth of formation and pressure of trap- ping}

The formation temperature estimated from fluid inclusion microthermometry can be used to infer formation depth of veins using the boiling point curve of Hass, 1971 (Shepherd et al, 1985). The formation temperature of each vein is plot on the temperature axis and the salinity value is plot on the curves of salinity. The formation temperatures and salinity of five veins are shown in Table 1 . According to plots of Th and Salinity values, estimated depths of formation are $270 \mathrm{~m}$ for Merpati vein, $360 \mathrm{~m}$ for Rini vein, $410 \mathrm{~m}$ for Dollah vein, $500 \mathrm{~m}$ for Arif vein, and $550 \mathrm{~m}$ for Jambu Air vein .The results for the depths of formation of five veins are shown in Figure 10.

If the fluid is boiling, the vapor pressure can be used to estimate the depth of trapping assuming a hydrological system open to the surface (Shepherd et al, 1985). At depths of less than approximately $3 \mathrm{~km}$ in the crust, fluid pressures are generally close to hydrostatic so that, the general formula relating pressure to depth can be used to estimate depth or pressure (Wilkinson, 2000).

$$
P=H \rho g
$$

where $H=\operatorname{depth} ; P=$ pressure $\rho=$ density of overlying material $\left(1.00 \mathrm{~g} \mathrm{~cm}^{-3}\right.$ for hydrostatic head, $2.70 \mathrm{~g} \mathrm{~cm}^{-3}$ for lithostatic overburden); $g$ $=$ acceleration due to gravity $=981$ dynes $\mathrm{cm}^{-2}$ on old c.g.s. unit system.

By using above formula, the formation pressure of each vein therefore can be calculated and estimated. Formation pressure of MV is 71.5 bars. Formation pressure of DV is 105.95 bars. Formation pressure of RV is 127.14 bars. Formation pressure of AV is 150.98 bars. Formation pressure of JV is 180.11 bars.

\section{Conclusion}

Fluid inclusion study is vey important to know the condition of hydrothermal fluids and their origin. Microthermometry results can be used to estimate formation temperature of the deposit and salinity of the responsible hydrothermal fluid. The formation temperature of Merpati Vein is between 220 and $230^{\circ} \mathrm{C}$, Dollah Vein (DV): $240-250^{\circ} \mathrm{C}$, Rini Vein (RV): $250-260^{\circ} \mathrm{C}$, Arif Vein (AV): $260-270^{\circ} \mathrm{C}$, and Jambu Air Vein (JV): $270-280^{\circ} \mathrm{C}$. The results of homogenization temperature (Th) are shown in Figure 5. Average melting temperature (Tm) of each vein is $1.88^{\circ} \mathrm{C}$ for Merpati vein, $-1.43^{\circ} \mathrm{C}$ for Dollah vein, $-0.93^{\circ} \mathrm{C}$ for Rini vein, $-1.13^{\circ} \mathrm{C}$ for Arif vein, and $-1.08^{\circ} \mathrm{C}$ for Jambu Air vein.

The data of homogenization temperature and salinity show that ore forming processes of the Soripesa prospect area were formed under the condition of epithermal system. The average salinity (wt.\% $\mathrm{NaCl}$ equiv.) of the fluid for all veins is 3.15 for Merpati vein, 2.44 for Dollah vein, 1.6 for Rini vein, 1.95 for Arif vein, and 1.86 for Jambu Air vein. Plots of Th and salinity of Merpati vein and Dollah vein show the trends of boiling processes. Th-salinity plots of Rini vein and Arif vein show a trend of isothermal mixing. Th-salinity plots of Jambu Air vein show a trend of surface fluid dilution processes. Estimation depths of formation are $270 \mathrm{~m}$ for Merpati vein, $410 \mathrm{~m}$ for Dollah vein, $360 \mathrm{~m}$ for Rini vein, $500 \mathrm{~m}$ for Arif vein, and $550 \mathrm{~m}$ for Jambu Air vein. Estimation pressure of trapping for each vein is 72 bars for Merpati vein, 106 bars for Dollah vein, 127 bars for Rini vein, 

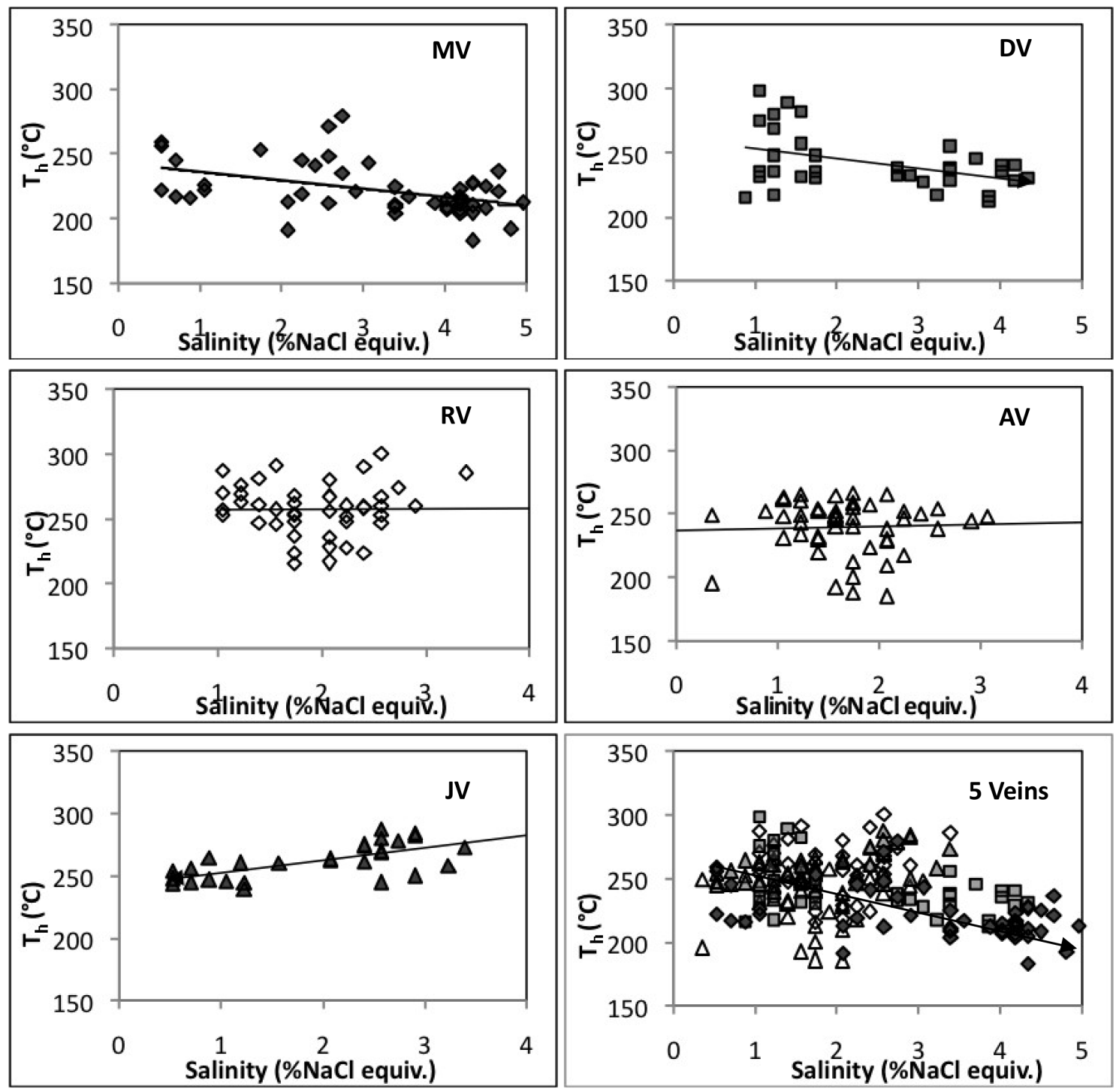

Figure 6: Plots showing homogenization temperature (Th) and salinity of 5 veins (MV = Merpati vein, DV = Dollah Vein, RV = Rini Vein, AV = Arif Vein, and JV = Jambu Air Vein). 
Table 1: Results for Th, Tm, and Salinity determination in fluid inclusions from quartz veins.

\begin{tabular}{|lrrrrr|}
\hline \multicolumn{1}{|c}{ Veins } & $T_{h}$ ranges & Average $T_{h}$ & $T_{m}$ ranges & Average $T_{m}$ & $\begin{array}{c}\text { Average } \\
\text { Salinity }\end{array}$ \\
\hline Merpati vein & $182-279$ & 224 & $-3.0--0.3$ & -1.88 & 3.15 \\
Dollah vein & $212-305$ & 248 & $-2.6--0.5$ & -1.43 & 2.44 \\
Rini vein & $185-266$ & 239 & $-1.8--0.2$ & -0.93 & 1.60 \\
Arif vein & $216-300$ & 256 & $-2.0--0.6$ & -1.13 & 1.95 \\
Jambu Air vein & $233-297$ & 263 & $-2.0--0.3$ & -1.08 & 1.86 \\
\hline
\end{tabular}

Table 2: Typical characteristics of fluid inclusions in hydrothermal ore deposits and this research.

\begin{tabular}{|c|c|c|c|c|}
\hline Deposit type & Host minerals & $T_{h}$ range $\left({ }^{\circ} \mathrm{C}\right)$ & $\begin{array}{c}\text { Salinity range (wt } \\
\% \mathrm{NaCl} \text { equiv.) }\end{array}$ & $\begin{array}{l}\text { Daughter } \\
\text { minerals }\end{array}$ \\
\hline This research & qtz & $182-305$ & $0-5$ & - \\
\hline $\begin{array}{l}\text { Mississippi } \\
\text { valley-type }\end{array}$ & $\mathrm{cc}, \mathrm{dol}, \mathrm{qz}, \mathrm{sph}$ & $50-180$ & $15-30$ & - \\
\hline VMS & qtz, ba & $80-340$ & $1-8$ & - \\
\hline $\begin{array}{l}\text { Porphyry- } \\
\text { copper }\end{array}$ & qtz & $200-700$ & $0-70$ & $\begin{array}{l}\text { hal, syl, chl, } \\
\text { cpy, hm }\end{array}$ \\
\hline Epithermal & $\mathrm{qtz}, \mathrm{cc}, \mathrm{sph}$ & $100-300$ & $0-12$ & - \\
\hline $\begin{array}{l}\text { Mesothermal } \\
\text { gold }\end{array}$ & $\mathrm{qtz}, \mathrm{cc}$ & $200-400$ & $2-10$ & - \\
\hline
\end{tabular}

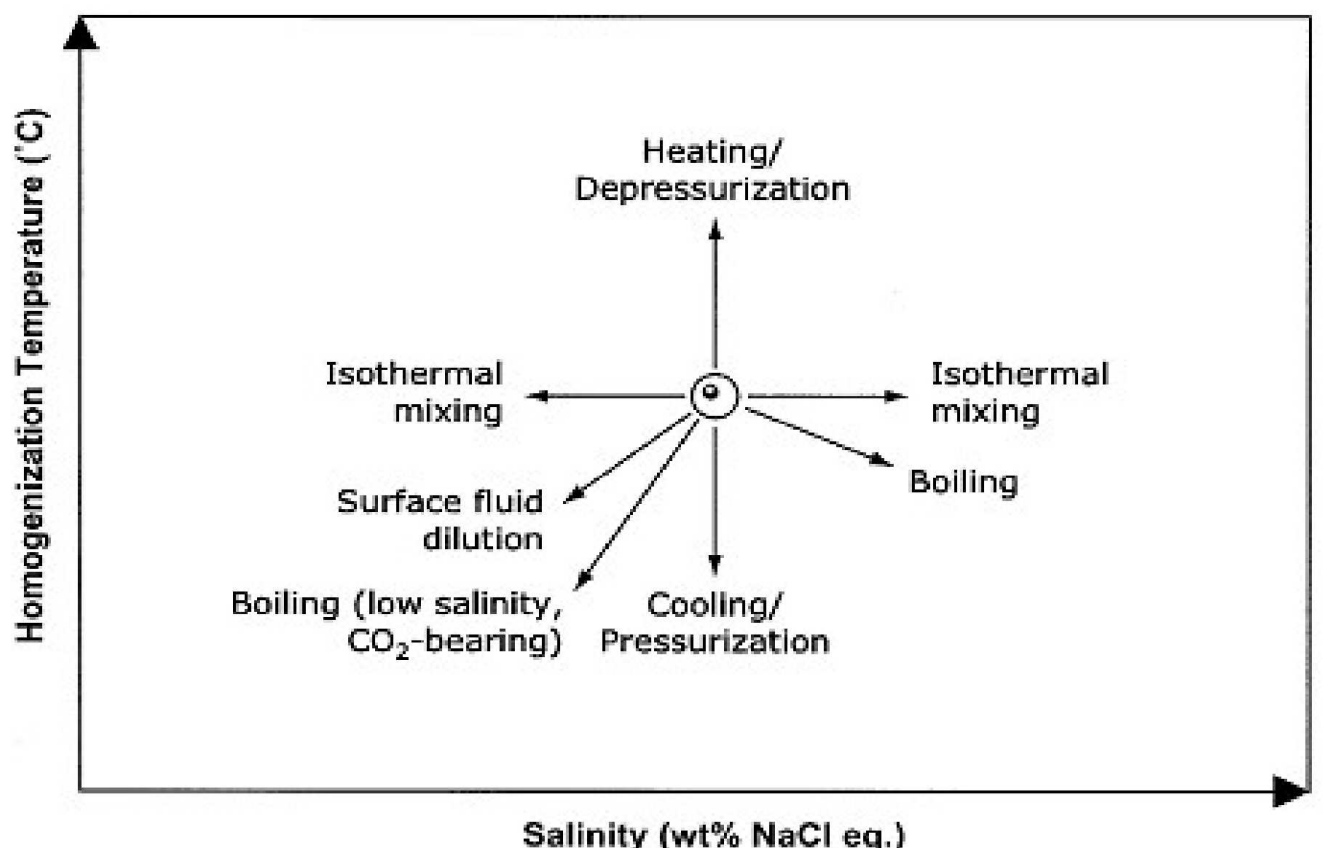

Figure 7: Schematic diagram showing typical trends in $\mathrm{Th}\left({ }^{\circ} \mathrm{C}\right)-$ Salinity space due to various fluid evolution processes (Wilkinson, 2001). 


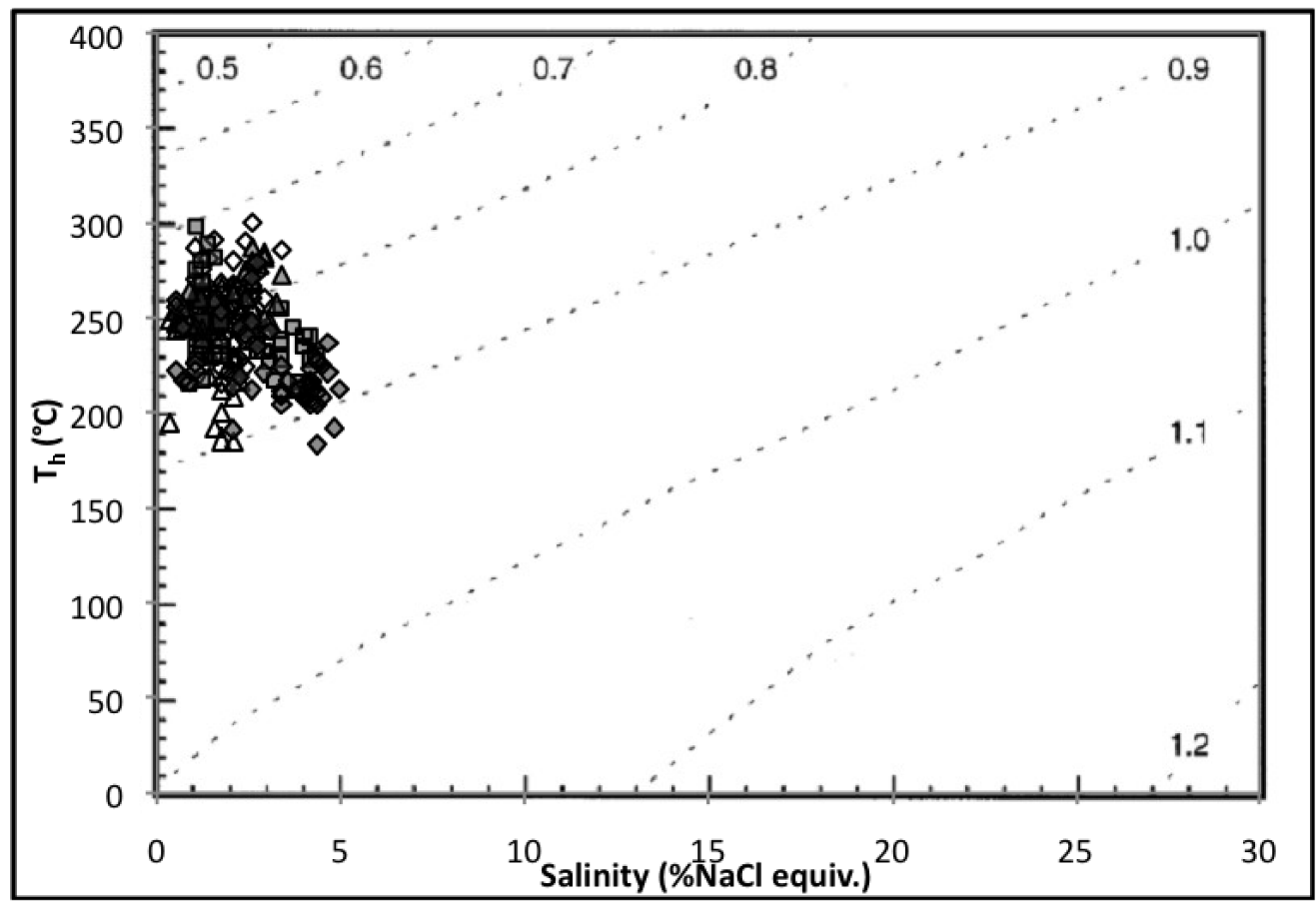

Figure 8: Temperature-salinity plot showing densities $\left(\mathrm{g} \mathrm{cm}^{-3}\right)$ of vapour-saturated $\mathrm{H}_{2} \mathrm{O}-\mathrm{NaCl}$ solutions (source: Wilkinson, 2001).

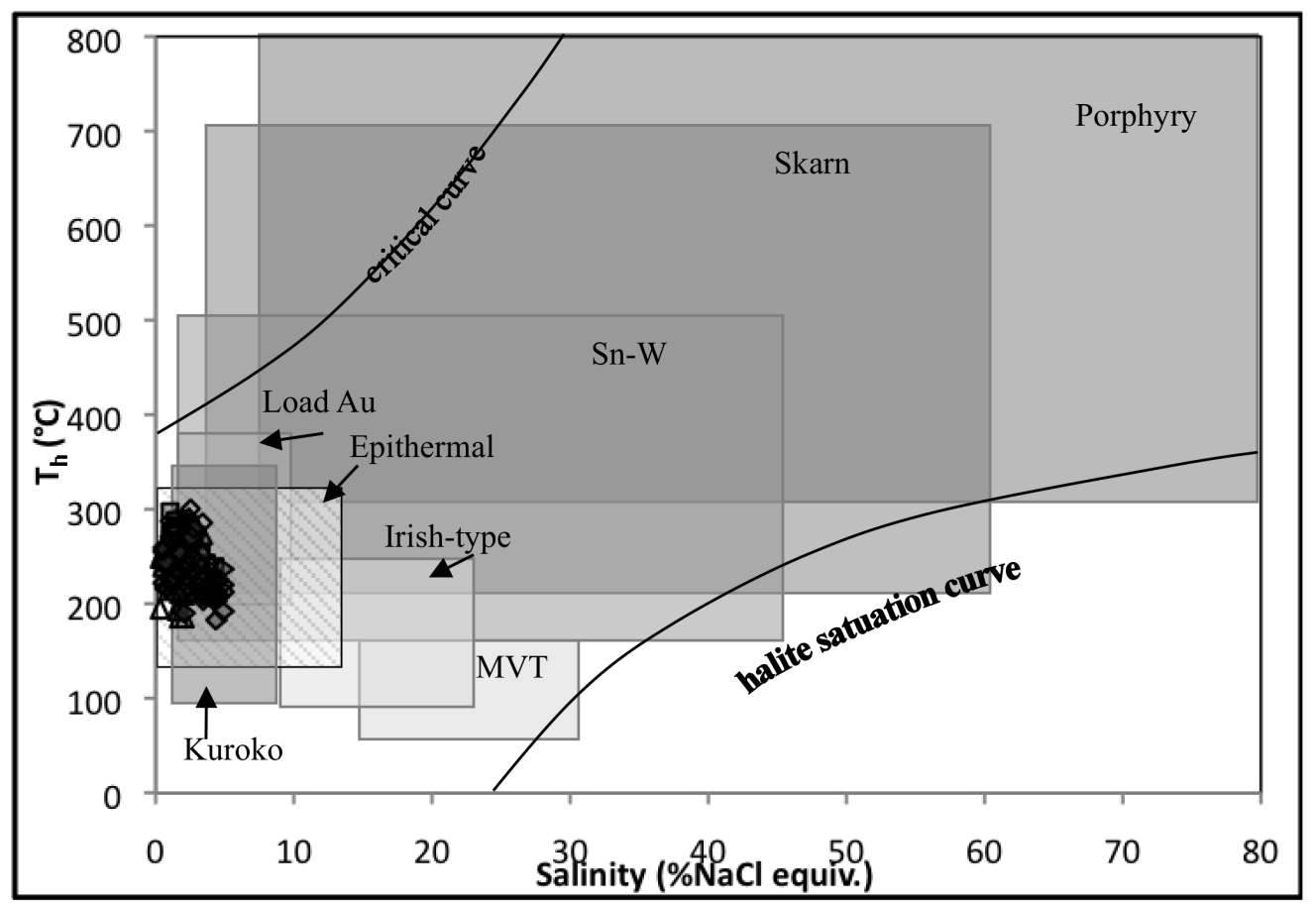

Figure 9: Th-salinity diagram illustrating typical ranges for inclusions from different deposit types. Note that fields should not be considered definitive and compositions exist outside the ranges shown (Source: Wilkinson, 2001). 


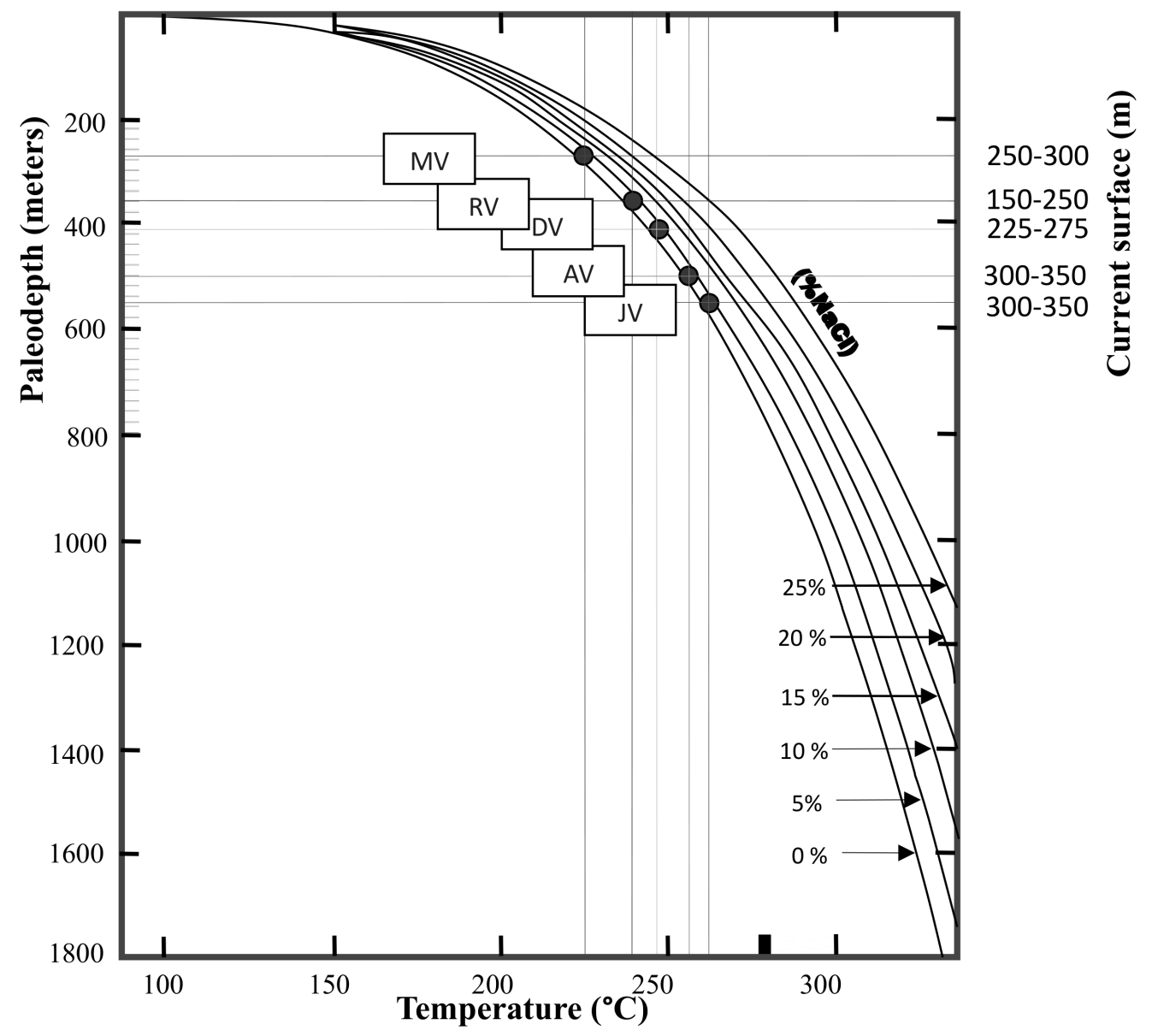

Figure 10: Th-salinity diagram illustrating typical ranges for inclusions from different deposit types. Note that fields should not be considered definitive and compositions exist outside the ranges shown (Source: Wilkinson, 2001). 
151 bars for Arif vein, and 180 bars for Jambu Air vein.

\section{Acknowledgement}

The authors want to express deep thanks to AUN/SEED-Net and JICA program for their financial supporting to do this research. And then, thankful acknowledgements are due to Indo mining group for their kind helps and permission during the field work. Finally, the authors wish to thank Earth Resources Engineering Department, Kyushu University for performing laboratory works and analyses.

\section{References}

Bodnar, R. J. (1993) Revised equation and table for determining the freezing point depression of $\mathrm{H}_{2} \mathrm{O}-\mathrm{NaCl}$ solution, Geochimica Acta 57: 683684.

Bodnar, R.J., Reynolds, T.J., Kuehn, C.A. (1985) Fluid-inclusion systematics in epithermal systems, In: Berger, B.R., Bethke, P.M. (Eds.) Geology and Geochemistry of Epithermal Systems. Reviews in Economic Geology, Society of Economic Geologists 2: 73-97.

Buchanan, L.J. (1981) Precious metal deposits associated with volcanic environments in the southwest, pp. 237-262 in W.R. Dickinson and W.D. Payne, Eds, Relation of Tectonics to Ore Deposits in the southern Cordillera. Tucson: Ariz. Geol. Soc. Dig. XIV, 288 pp.

Carlile, J.C. and Mitchell, A.H.G. (1994) Magmatic arcs and associated gold and copper mineralization in Indonesia, Journal of Geochemical Exploration 50: 91-145.

Haas, J.L. (1971) The Effect of Salinity on the Maximum Thermal Gradient of a Hydrothermal System at Hydrostatic Pressure, Economic Geology 66: 940-946.

Hall, R. (2009) Indonesia Geology, Royal Holloway University of London, pp. 454-460.

Hamilton, W. (1974) Tectonics of the Indonesian region:. U.S. Geol. Surv., Prof. Pap. 1078p.

Khant, W., Warmada, I W., Idrus, A., Satijadji, L.D., and Watanabe, K. (2012) Alteration Mineralogy and Quartz Textures of Polymetallic Epithermal Quartz Veins at Soripesa Prospect Area, Sumbawa Island, Indonesia. 2nd Asia Africa Mineral Resources Conference Bundung, 14-17 September, 2012.

Noya, Y., Effendhy, O., Hamdan Abidin, Z., and Pakaya, Y. (2009) Geological background and economic prospect of the Soripesa deposit, eastern Sumbawa, Proceeding pit IAGI Semarang, 2009. The 38th IAGI annual Convention and Exhibition Semarang, 13-14, October.

Roedder, E. (1984) Fluid inclusions, Mineralogical Society of America. Reviews in Mineralogy 12, $644 \mathrm{p}$.

Shepherd, T.J. (1985) A Practical Guide to Fluid Inclusion Studies, Balckie, 237 p.

Wilkinson, J.J. (2001) Fluid inclusions in hydrothermal ore deposits. Lithos 55: 229-272. 